Prawo Kanoniczne $61(2018) \mathrm{nr} 2$

DOI:10.21697/pk.2018.61.2.01

S. BOŻENA SZEWCZUL WNO

Wydział Prawa Kanonicznego

Uniwersytetu Kardynała Stefana Wyszyńskiego w Warszawie

\title{
ZNACZENIE PRACY W ŻYCIU PIERWSZYCH MNICHÓW CHRZEŚCIJAŃSKICH
}

Treść: Wprowadzenie. - 1. Etymologia słowa „praca”. - 2. Pismo Święte pierwszą regułą mnichów odnośnie do pracy. - 3. Praca mnichów realizacją wskazań Pisma Świętego. - 3.1. Rola pracy w życiu Chrystusa i Apostołów. - 3.2. Praca udziałem w dziele zbawczym Chrystusa. - 3.3. Łączenie pracy mniszej z modlitwą - ora et labora. - 3.3.1. Modlitwa jako praca i praca jako modlitwa. - 3.3.2. Pracowitość a lenistwo - 3.3.2.1. „Bezczynność jest wrogiem duszy" -3.3.2.2. Przepracowywanie się. - 4. Prymat zbawczego charakteru pracy mniszej. - 5. Szczególne uzdolnienia mnichów i prace im zalecane. - 6. Praca umożliwia dobroczynność. - 7. Sposób wykonywania pracy. - 8. Ascetyczny wymiar pracy. - Zakończenie.

\section{Wprowadzenie}

Problemy dotyczące niektórych aspektów pracy ludzkiej, regulowane w prawie cywilnym, obecne także w dziedzinie socjologii, antropologii i teologii, zajmują niewiele miejsca w literaturze prawa kanonicznego, a szczególnie w tej dotyczącej życia zakonnego, mimo że zagadnienie pracy nie jest obce prawu kanonicznemu ani - tym bardziej - życiu monastycznemu z jego paremią „módl się i pracuj”. Termin „praca” występuje 4 razy w Kodeksie Prawa Kanonicznego z 1983 roku (kan. $246 \$ 2,689 \$ 2,792,1247)^{1}$, w kontekście świętowania

\footnotetext{
${ }^{1}$ L. Chiappetta, Dizionario del nuovo codice di diritto canonico, Napoli $1986^{2}$, s. 540 .
} 
niedzieli i świąt nakazanych, imigrantów przybywających z terenów misyjnych, prac apostolskich podejmowanych przez duchownych i zakonników. Ostatni rodzaj pracy jest obecny w Kodeksie w różnych ujęciach 13 razy, z czego 5 zastosowań dotyczy członków instytutów życia konsekrowanego i stowarzyszeń życia apostolskiego w ramach wykonywanych przez nich dzieł apostolskich, miłosierdzia i miłości² Dodatkowo, w kanonie 600, podającym definicję ewangelicznej rady ubóstwa realizowanej przez zakonników, prawodawca używa np. terminu vita operosa in sobrietate czyli życie pracowite $w$ umiarze, wskazując tym samym na obowiązek pracy zakonników, wynikający $\mathrm{z}$ podjęcia przez nich życia w ubóstwie.

Obserwacja funkcjonowania zgromadzeń zakonnych sprawia, że wyraźna staje się potrzeba głębszej refleksji nad zagadnieniem pracy w życiu współczesnych zakonników, z jednoczesnym sięgnięciem do początków życia monastycznego (zgodnie z zachętą Soboru Watykańskiego II do powrotu do najgłębszych źródeł życia chrześcijańskiego³). Wydaje się, że zakonnicy zagubili sens wykonywanej przez siebie pracy, jej rozumienie i właściwe do niej podejście. Z jednej strony praca często staje się najważniejszą częścią życia zakonnika, pociągając za sobą zaniedbanie modlitwy, udziału w życiu wspólnoty, wypalenie duchowe i ciągłe zmęczenie. $Z$ drugiej jednak strony zaobserwować można wzmagające się lenistwo zakonników, ograniczenie wykonywanej pracy do niezbędnego minimum. Poza tym praca, zajmująca zakonnikom większą część dnia, traci wielokrotnie swój apostolski charakter, coraz mniej mówiąc współczesnym ludziom o ścisłym powiązaniu codziennie wykonywanych obowiązków z Bogiem.

\section{Etymologia słowa praca}

Z punktu widzenia etymologicznego, polski wyraz „praca” pochodzi od słowiańskiego słowa pratili, oznaczającego posyłanie,

\footnotetext{
${ }^{2}$ Tamże, s. 678-679.

${ }^{3}$ Sobór Watykański II, Dekret o przystosowanej do współczesności odnowie życia zakonnego «Perfectae caritatis», nr 2, w: Sobór Watykański II, Konstytucje, dekrety, deklaracje. Tekst polski. Nowe tłumaczenie, Poznań 2002, s. 265.
} 
ponoszenie trudu związanego z noszeniem, branie ciężaru na siebie ${ }^{4}$. Terminami bliskoznacznymi dla polskiego określenia „praca” są: zajęcie, służba, urzędowanie, zarobkowanie, działalność (intensywna, owocna, gorączkowa, działalność literacka, społeczna, polityczna), akcja, robota (trudna), orka, harówka, pańszczyzna. Zaś sama praca, jak wynika ze słownika wyrazów bliskoznacznych może być: usilna, znojna, syzyfowa, zarobkowa, przymusowa, zawodowa, praca za wynagrodzeniem ${ }^{5}$. Wyjaśniwszy w ten sposób termin „praca”, redaktorzy Słownika wyrazów bliskoznacznych odsyłają do haseł - „wysiłek” i „działanie”. Znaczenie pierwszego z wymienionych słów wynika między innymi z położenia akcentu na konieczne wytężenie sił, jakie jest konieczne w pracy i które określać można jako: trud, mozól, krwawicę, mordęgę, męczarnię, katorgę i kierat. Natomiast sam wysiłek może być: ogromny, daremny, zorganizowany, może spełznąć na niczym, dotyczyć woli, rąk i mózgu ${ }^{6}$. Działanie zaś, odnoszące się do czynności, funkcjonowania, akcji lub operacji wiąże się zawsze z koniecznością wykonywani pewnej pracy ${ }^{7}$.

Francuskie słowo, określające pracę - travail (podobnie hiszpańskie trabajo) - pochodzi od łacińskiego tripalus i oznacza również zmęczenie, trud, zainwestowanie energii oraz wysiłek, który powoduje zmęczenie. Samo zaś słowo tripalus wskazuje na narzędzie używane dla utrzymania w bezruchu wołów i koni podczas ich podkuwania. Czasownik tripalare tłumaczy się natomiast na język polski jako „torturować”, co podkreślać może również konieczność zmuszania ciała do wysiłku i znoszenia niewygód ${ }^{8}$.

Podobnie jest też z łacińskim wyrazem labor, oznaczającym wysiłek, trud, pracę, uciążliwość, zmęczenie, cierpienie, ból, a nawet

\footnotetext{
${ }^{4}$ ST. SKorupka, Słownik wyrazów bliskoznacznych, Warszawa 1968, s. 159.

${ }^{5}$ Słownik wyrazów bliskoznacznych. Wydanie poszerzone i zaktualizowane (red. D. Ludwiczak, A. Piskadłowa, E. Tarka-Huczek), Warszawa 1998, s. 178.

${ }^{6}$ Tamże, s. 285-286.

${ }^{7}$ Tamże, s. 51.

${ }^{8}$ H. Rondet, Elementi per una teologia del lavoro, w: AA.VV., Per una teologia della creazione e del lavoro, Roma 1967, s. 104; A. SKowroneK, W kierunku teologii pracy, Śląskie Studia Historyczno-teologiczne 6(1973), s. 5.
} 
nieszczęście, zarazę, od którego pochodzi czasownik „pracować”. Czy taka etymologia wynikać może ze starożytnej mentalności, uznającej konieczność pracy fizycznej za nieszczęście, a samą pracę za zajęcie niegodne arystokraty, człowieka szanowanego? Łacińskie laboro oznacza: natężać się, dążyć do czegoś, zabiegać o coś, cierpieć, znajdować się w potrzebie, w kłopocie, w trudnym położeniu, w niedostatku, umęczyć się, cierpieć fizycznie, chorować .

Z powyższego przeglądu wieloznaczności słowa „praca” jasno wynika, że jest ona pewnym wysiłkiem fizycznym, intelektualnym lub dotyczącym woli związanym zawsze $z$ bezspornym trudem, cierpieniem i zmęczeniem. Dotyczy to w zasadzie każdej aktywności podejmowanej przez człowieka.

\section{Pismo Święte pierwszą regułą mnichów odnośnie do pracy}

Monastycyzm (od greckiego słowa monos - sam jeden, samotny), jako jedna z najstarszych form poświęcenia życia Bogu, jest obecny już w początkach chrześcijaństwa, stąd siłą rzeczy zaczyna kształtować się jeszcze w świecie pogańskim, w którym każda praca, także artystyczna, a zwłaszcza praca fizyczna była deprecjonowana i uważana za niegodną człowieka wolnego, oceniana jako czynność poniżająca i hańbiąca. Nie harmonizowała ona z powagą umysłu człowieka wolnego, ponieważ krępowała, wiązała i uzależniała od siebie. Poza tym praca fizyczna, z uwagi na związany z nią wysiłek, uważana była wówczas za coś, co niszczy ciało ludzkie i źle oddziaływuje na ducha ludzkiego. Była więc uważana za rzecz ze wszech miar szkodliwą, a jej hańbiący charakter zdecydował o tym, że stała się domeną niewolników, ludzi traktowanych pogardliwie, jak przedmioty czy juczne zwierzęta. Natomiast ludzie wolni, dobrze urodzeni, oddawali się rzeczom wyższym - studiosum otium. Ich ideałem, w myśl formuły grecko-rzymskiej stało się próżnowanie, otium, deus

\footnotetext{
${ }^{9}$ A. Jugan, Słownik kościelny łacińsko-polski, Warszawa 1992³ , s. 373; J. SondeL, Słownik łacińsko-polski dla prawników i historyków, Kraków 1997, s. 553.
} 
otiosus $^{10}$. System niewolniczy i feudalny przyczynił się ostatecznie do powstania ideologii nieposzanowania pracy i pogardy dla niej. Chrześcijanie natomiast, a więc także i mnisi, wykonując swe prace, opierali się na wskazaniach Pisma Świętego. Zwłaszcza zasady ewangeliczne w tym względzie były pierwszą regułą monastyczną, a nawet gdy pojawiły się reguły monastyczne sensu stricte - wciąż niosły one w sobie ewangeliczne odniesienia do pracy Chrystusa i Apostołów ${ }^{11}$.

Apostołowie, ludzie pracy byli powoływani przez Chrystusa do pójścia za Nim w trakcie wykonywania przez nich swej pracy - niektórzy przy połowie ryb, Mateusz zaś przy bankierskim stole ${ }^{12}$. Po zmartwychwstaniu Mistrza Apostołowie powrócili do swej dawnej pracy fizycznej. Wszystko to przyczyniło się do poszanowania i czci, jaką zaczęto otaczać pracę w pierwszych gminach chrześcijańskich, a w konsekwencji - również w nawiązującym do nich życiu pustelniczym i wspólnotach monastycznych ${ }^{13}$.

\section{Praca mnichów realizacją wskazań Pisma Świętego}

Już na wstępie Biblii, w Księdze Rodzaju, Bóg jawi się jako początek wszelkiego działania i ruchu, a Jego dzieło stwórcze, dokonane w ciągu sześciu dni, jest niestrudzoną pracą. Od tego momentu wszystko, co żyje, rośnie, porusza się i działa we wszechświecie, zawdzięcza swoje istnienie Bogu. Również działanie współczesnego człowieka w dobie rozwiniętej techniki i urbanizacji, dokonuje się

\footnotetext{
${ }^{10}$ L. Civardi, Il lavoro nel concetto cristiano, Torino 1957, s. 25; Cz. S. BARTniK, Wstęp, w: S. Wyszyński, Duch pracy ludzkiej. Myśli o wartości pracy, Warszawa 2001, s. 8.

${ }^{11}$ Benedy kt z Nursji, Reguła, (przekład A. Świderkówna), Tyniec $1997^{2}$, rozdz. 48, 8-9, s. 175: „są prawdziwymi mnichami, jeśli żyją z pracy rąk swoich, jak Ojcowie nasi i Apostołowie".

${ }^{12}$ Mt 1, 16-20; 9,9; M. MAzzeo, La dignità della persona che lavora dalle origini fino a Gesù (Mt 20, 1-16), w: AA. VV., «La grazia di lavorare». Lavoro, vita consacrata, francescanesimo, (a cura di P. Martinelli e M. Melone), Edizini Dehoniane, Bologna 2015, s. 195-196.

${ }^{13}$ ST. Wyszyński, Duch pracyludzkiej..., s. 33.
} 
mocą Boga ${ }^{14}$, który działa aż do tej chwiliti ${ }^{15}$, a Jego praca stanowi wzór dla każdej pracy ludzkiej. Prymas kard. Stefan Wyszyński w książce pt. Duch pracy ludzkiej stwierdza, że człowiek tak naprawdę nie tworzy, a jedynie przetwarza gotowe dary Boże, jest współpracownikiem Boga, Jego pomocnikiem, przygotowanym uprzednio przez Stwórcę dzięki obdarowaniu go rozumną wolą, zdolną do poznania i wykonania zamiaru Boga ${ }^{16}$. Bóg Stwórca zaprasza jednocześnie człowieka stworzonego na Jego obraz (Rdz 1,27), jeszcze przed ukończeniem dzieła stwórczego, do współpracy, aby czynił sobie ziemię poddaną ${ }^{17}$, aby swą pracą dopełniał dzieło stwórcze Boga, aby odsłaniał zasoby i wartości ukryte w stworzeniu ${ }^{18}$.

Co więcej, Bóg pragnie posługiwać się człowiekiem w swym dziele, ponieważ mógłby bardzo dobrze sam uczynić materię według swych planów i naszych potrzeb ${ }^{19}$. I nie chodzi tu o prace wyszukane, ale o zwykłe, codzienne zajęcia, które - wbrew pozorom - są udziałem w dziele stwórczym Boga ${ }^{20}$.

Bóg kończy pracę odpoczynkiem²1, który stanowi ukończenie działalności stwórczej. Praca i odpoczynek Boga są ściśle ze sobą związane i nie można ich od siebie oddzielić. Stąd człowiek, jako jedyny stworzony na obraz i podobieństwo Boga, powinien Go naśladować, zarówno w pracy, jak i w odpoczynku. Związek ten jest

${ }^{14}$ C. Westermann, Lavoro e attività culturale nella Bibbia, Concilium Rivista Internazionale di Teologia 16/1(1980), s. 1191; M. MAzzEO, La dignità della persona..., s. 194; ST. WYsZy ŃsKi, Duch pracyludzkiej..., s. 27.

${ }^{15}$ J 5,17: „Ojciec mój działa aż do tej chwili i Ja też działam”.

${ }^{16}$ L. Civardi, Il lavoro nel concetto cristiano, s. 45; ST. WyszyńsKi, Duch pracy ludzkiej..., s. 30 .

${ }^{17} \mathrm{Rdz} 1,28$.

${ }^{18}$ Jan PAWe£ II, Encyklika «Laborem exercens», nr 25, https://opoka.org.pl/ biblioteka/W/WP/jan_pawel_ii/encykliki/laborem.html (dalej: Laborem exercens).

${ }^{19}$ L. Civardi, Il lavoro nel concetto cristiano, s. 45.

${ }^{20}$ Laborem exercens, $\mathrm{nr} 25$.

${ }^{21}$ Rdz 2,2: „A gdy Bóg ukończył w dniu szóstym swe dzieło, nad którym pracował, odpoczął dnia siódmego po całym swym trudzie, jaki podjął”. 
wskazaniem służącym właściwemu zrozumieniu sensu i godności życia oraz pracy ludzkiej ${ }^{22}$.

\subsection{Rola pracy w życiu Chrystusa i Apostołów}

Nowotestamentalne nauczanie na temat pracy nie ma źródła jedynie w głoszonej przez Chrystusa Dobrej Nowinie, lecz ma swoje źródło przede wszystkim w samej Jego Osobie. Chrystus pracuje, powołując się na przykład swego Ojca niebieskiego, który mówi: „Ojciec działa aż do tej chwili i Ja też działam”23. Sam Jezus przez 30 lat wykonywał własnymi rękami szarą i żmudną pracę w warsztacie ciesielskim w Nazarecie, stąd w opinii sobie współczesnych słusznie uchodził za rzemieślnika z Nazaretu. Przywrócił tym samym wartość pracy i obdarzył nową godnością pracownika fizycznego, zrównanego w czasach pogańskich ze zwierzęciem ${ }^{24}$. Również praca na roli i w winnicy nie była Jezusowi obca, o czym świadczą przytaczane przez Niego szczegółowe przypowieści z tej dziedziny. Następnie realizacja misji od momentu przyjęcia Jego przesłania przez naród wybrany aż do odrzucenia Go i śmierci na krzyżu była wyczerpującą pracą, do tego stopnia, że wraz z Apostołami nie mieli czasu nawet na posiłek ${ }^{25}$. Stąd Chrystus zachęca Apostołów, aby udali się czasem na miejsce pustynne sami, osobno i odpoczęli nieco, sam również udaje się samotnie w różne miejsca, aby się modlić. Jezus zachowuje również odpoczynek w siódmym dniu, dniu poświęconym swojemu Ojcu. Tak więc Chrystus zbawił świat nie tylko przez mękę, śmierć na krzyżu i zmartwychwstanie, ale także przez swą pracę, wykonywaną

\footnotetext{
${ }^{22}$ Laborem exercens, nr 25; M. MAzzeo, La dignità della persona..., s. 194; A. SiEMIENIEWski, Duchowość pracy, http://www.siemieniewski.archidiecezja.wroc. $\mathrm{pl} /$ ?q=node/61 [dostęp 23.05.2017].

${ }^{23} \mathrm{~J} 5,17$.

${ }^{24}$ L. Civardi, Il lavoro nel concetto cristiano, s. 49.

${ }^{25}$ Mk 6,31: „A On rzekł do nich: Pójdźcie wy sami osobno na miejsce pustynne i wypocznijcie nieco!. Tak wielu bowiem przychodziło i odchodziło, że nawet na posiłek nie mieli czasu."
} 
w trudzie. Nie tylko rękami przybitymi do krzyża, ale także rękami utrudzonymi pracą, czyli przez wysiłek fizyczny ${ }^{26}$.

Również św. Paweł, wzorem swojego Mistrza, wysoko cenił wartość pracy. Znany z głoszenia maksymy: „Kto nie chce pracować niech też nie je"27, Apostoł Narodów zrezygnował z możliwości życia tylko z Ewangelii, tj. utrzymania go przez wierzących jako głosiciela Ewangelii i pracował własnymi rękami w swoim zawodzie, najprawdopodobniej jako wytwórca namiotów, aby nie być ciężarem dla nikogo ${ }^{28}$ i aby móc ze spokojem zachęcać do pracowitego życia czy nawet nakazywać w Chrystusie innym, aby, pracując ze spokojem, własny chleb jedli ${ }^{29}$.

\subsection{Praca udziałem w dziele zbawczym Chrystusa}

Z Pisma Świętego oraz przykładu życia Chrystusa i Apostołów jasno wynika, że praca będąca początkowo, tzn. przed grzechem Adama, tylko radosnym współudziałem w dziele stwórczym Boga, złączyła się następnie z trudem ${ }^{30}$. Po grzechu pierworodnym praca

${ }^{26}$ L. Civardi, Il lavoro nel concetto cristiano, s. 50.

${ }^{27} 2$ Tes 3,10 .

${ }^{28} 2$ Tes 3, 7-12: „Sami bowiem wiecie, jak należy nas naśladować, bo nie wzbudzaliśmy wśród was niepokoju ani u nikogo nie jedliśmy za darmo chleba, ale pracowaliśmy w trudzie i zmęczeniu, we dnie i w nocy, aby dla nikogo z was nie być ciężarem. Nie jakobyśmy nie mieli do tego prawa, lecz po to, aby dać wam samych siebie za przykład do naśladowania. Albowiem gdy byliśmy u was, nakazywaliśmy wam tak: Kto nie chce pracować, niech też nie je! Słyszymy bowiem, że niektórzy wśród was postępują wbrew porządkowi: wcale nie pracują, lecz zajmują się rzeczami niepotrzebnymi. Tym przeto nakazujemy i napominamy ich w Panu Jezusie Chrystusie, aby pracując ze spokojem, własny chleb jedli”; Dz 20,34; Augustry z Hippony, O pracy mnichów (przekład i komentarz R. Szaszka), w: Św. Augustyn. Pisma monastyczne. Źródła monastyczne t. 27, (red. M. Starowieyski), Kraków 2002, s. 194-206; L. Civardi, Il lavoro nel concetto cristiano, s. 60; A.M. Buscemi, Tutto fate nel nome di Gesù. Il lavoro in san Paolo, w: AA. VV., "La grazia di lavorare». Lavoro, vita consacrata, francescanesimo, (a cura di P. Martinelli e M. Melone), Edizioni Dehoniane, Bologna 2015, s. 231-232.

${ }^{29} 2$ Tes 3,12.

${ }^{30} \mathrm{Rdz}$ 3, 17-19: „w trudzie będziesz zdobywał od niej pożywienie dla siebie po wszystkie dni twego życia. Cierń i oset będzie ci ona rodziła, a przecież pokarmem 
stała się pokutą za popełniony czyn, grzech przysporzył jej ciężaru, zmęczenia, potu i znużenia. Od tej pory człowiek musiał zdobywać środki do życia w połączeniu z ogromnym trudem, co sprawiło, że poczuł on lęk i wewnętrzny opór przed najmniejszym wysiłkiem ${ }^{31}$.

Ciężar i znój związane z pracą mają jednak ogromną wartość, pozwalając każdemu człowiekowi, zmierzającemu do naśladowania Chrystusa na uczestnictwo w Jego dziele zbawczym, które dokonało się również przez cierpienie i śmierć krzyżową. Podejmując trudy pracy w zjednoczeniu z Chrystusem ukrzyżowanym, biorąc każdego dnia swój krzy $\dot{z}^{32}$ życia dla naśladowania Chrystusa, człowiek współpracuje z Nim w odkupieniu całej ludzkości, uczestniczy w Jego zbawczej misji. Praca ludzka staje się w ten sposób częścią Chrystusowego życia, oraz krzyża i może być przyjmowana w duchu odkupienia, podobnie jak przyjęcie krzyża za człowieka przez Chrystusa ${ }^{33}$.

Praca Chrystusa miała charakter nie tylko zbawczy, wynagradzający, ekspiacyjny, ale także uświęcający. Nie tylko służy otrzymaniu przebaczenia za popełniony grzech prarodziców, ale także pomnaża łaskę uświęcającą, jeżeli jest wykonywana zgodnie z zamysłem chrześcijańskim, wyrażającym się w wierze w to, że wszystko, co chrześcijanin czyni w stanie łaski i dla chwały Bożej, nabywa charakteru nadprzyrodzonego i zasługuje na wieczność. Skoro, zgodnie z nauczaniem św. Pawła, możemy czynić ponadnaturalnymi najzwyklejsze czynności dnia, jak jedzenie i picie, to tym bardziej uświęceniu podlega praca, która jest szlachetną aktywnością człowieka ${ }^{34}$. Przekonanie to najcelniej wyrazili może mnisi, którzy, dążąc do wiernego naśladowania Chrystusa, postanowili kierować się w swym życiu sentencją ora et labora. Dla współczesnego chrześcijanina, a zwłaszcza

\footnotetext{
twym są płody roli. W pocie więc oblicza twego będziesz musiał zdobywać pożywienie".

${ }^{31}$ ST. Wyszyński, Duch pracy ludzkiej..., s. 83-84.

${ }^{32}$ Łk 9, 23.

${ }^{33}$ Laborem exercens, nr 27.

${ }^{34}$ Kor 10, 31: „Przeto czy jecie, czy pijecie, czy cokolwiek innego czynicie, wszystko na chwałę Bożą czyńcie”; L. Civardi, Il lavoro nel concetto cristiano, s. 48-49.
} 
dla zakonnika, praca powinna być między innymi środkiem wynagrodzenia za grzechy i uświęcenia życia ${ }^{35}$.

\section{3. Łączenie pracy mniszej z modlitwą - ora et labora}

Charakterystyczną cechą ojców pustyni oraz mnichów żyjących w klasztorze było umiejętne połączenie modlitwy i pracy, a więc życie według maksymy ora et labora, identyfikowanej z późniejszym monastycyzmem benedyktyńskim. I chociaż nie występuje ona w powyższym brzmieniu ani w Regule św. Benedykta, ani też w apoftegmatach ojców pustyni, to jednak sposób życia pustelników, a następnie cenobitów, jasno ją potwierdza. Przyglądając się dokładniej pracy jednych i drugich można dostrzec jej ścisły związek ze wskazaniami Pisma Świętego, gdyż ono właśnie stanowiło pierwszą regułę życia monastycznego.

\subsubsection{Modlitwa jako praca i praca jako modlitwa}

Żywot św. Antoniego, napisany przez św. Atanazego Aleksandryjskiego, ukazuje ojca pustelników, który pracował własnymi rękami, ponieważ wcześniej usłyszał czytane słowa św. Pawła Apostoła: „Kto nie chce pracować niech też nie je" (2 Tes 3,10). Część dochodów swej pracy pozostawiał on na chleb dla siebie, a resztą przeznaczał dla ubogich. Modlił się nieustannie, ponieważ usłyszał, że jest napisane, aby nieustannie się modlić - najchętniej oddawał się recytacji psalmów i medytacji pozostałych ksiąg Pisma Świętego ${ }^{36}$. Ścisłe łączenie modlitwy z pracą, wypełniających cały dzień św. Antoniego, stało się bezpieczną drogą do zbawienia podtrzymywaną przez jego uczniów.

Dla ojców pustyni podstawową pracą była modlitwa, modlitwa uwielbienia Boga, ciągłego szukania Go oraz bezpośrednia adoracja. Była to tzw. praca wewnętrzna, którą uważano za główne zajęcie,

\footnotetext{
${ }^{35}$ L. Civardi, Il lavoro nel concetto cristiano, s. 50.

${ }^{36}$ Atanazy Aleksandry jski, Żywot św. Antoniego. Św. Antoni Pustelnik. Pisma, (przekł. Z. Brzozowska i inni), Warszawa 1987, s. 58; L. DAtTrino, Il primo monachesimo, Roma 1984, s. 17.
} 
podczas gdy rękodzieło uznawane było za coś ubocznego ${ }^{37}$. W jednym $z$ apoftegmatów można przeczytać: „Konieczna jest praca wewnętrzna, ponieważ dla niej tu przyszliśmy. Wielki to trud mówić ustami, a nie jest to praca fizyczna"38.

Ale także i praca fizyczna była postrzegana jako modlitwa - proste zajęcia, wykonywane w warunkach milczenia, kontemplacji, spokoju, tak, że trudno było oddzielić jedną od drugiej. Pracę określano mianem „dzieła duchowego" 39 . Kiedy pustelnik wyplatał kosze i przy tym modlił się, jak zwykł to zawsze czynić, trudno było określić, czy modli się pracując, czy też pracuje modląc się. Monastycyzm bardzo przyczynił się do połączenia pracy fizycznej z pracą duchową dzięki wysokiemu stopniu kontemplacji. Mnisi pachomiańscy, czyli cenobici zamieszkujący w klasztorach założonych przez św. Pachomiusza, twórcę życia cenobickiego na Wschodzie, nie mogli trwać bezczynnie, nawet na zgromadzeniu modlitewnym. Tylko bracia chorzy byli zwolnieni z pracy w tym czasie ${ }^{40}$.

Św. Augustyn z Hippony opisuje łączenie pracy z modlitwą w ten sposób: „Mnisi zatem bez przeszkód mogą śpiewać pobożne pieśni także w czasie wykonywania prac ręcznych i w ten sposób jakby niebiańskim rytmem lagodzić sam trud... Cóż zatem stoi na przeszkodzie, żeby sługa Boży wykonując prace ręczne rozmyślał nad prawem Pańskim i śpiewał psalm Imieniu Pana najwyższego" ${ }^{11}$.

${ }^{37}$ Teodor z Ferme 10, w: Apoftegmaty ojców pustyni. t. 1.Geronticon. Źródła monastyczne (red. M. Starowieyski), t. 4, Kraków 2007, s. 241.

${ }^{38}$ Apoftegmaty ojców pustyni. t. 2. Kolekcja systematyczna. Źródła monastyczne (red. M. Starowieyski), t. 9, Kraków 1995, s. 209.

${ }^{39}$ E. GHini, I padri del deserto. IV - La realtà del lavoro, Rivista di Vita Spirituale, 28(1974), s. 324; A. De VogüE, Lavoro. III. In Occidente, Dizionario degli istituti di perfezione, vol. V, Roma 1978, kol. 520.

${ }^{40}$ Pachomiusz, Reguła-Przykazania 5, w: Pachomiana latina. Źródła monastyczne, t. 11, (red. M. Starowiejski) Kraków 1996, s. 129: „Nie siedź bezczynnie na zgromadzeniu [modlitewnym], lecz szybką pracą rąk przygotuj osnowy i wątki na maty. Zwolnieni są tylko słabi fizycznie i tym pozwala się nie brać udziału w tej pracy”.

${ }^{41}$ Augustyn z Hippony, O pracy mnichów, s. 227. 


\subsubsection{Pracowitość a lenistwo}

Konieczność podejmowania pracy przez mnicha każdego dnia była czymś oczywistym w środowiskach monastycznych. Św. Benedykt z Nursji podkreśla ten obowiązek w swej Regule, poświęcając mu cały 48 rozdział. Co więcej, ten twórca monastycyzmu na Zachodzie uzależnia prawdziwość życia mniszego właśnie od pracy, gdyż jego zdaniem tylko ten jest autentycznym mnichem, kto żyje z pracy rąk własnych, podobnie, jak czynili to Apostołowie i Ojcowie pustyni ${ }^{42}$.

Św. Bazyli na postawione pytanie, czy należy pracować oraz czy można zaniedbywać pracę pod pretekstem modlitwy, odpowiada wprost, że należy pracować wytrwale, gdyż robotnik jest wart strawy $y^{43}$. Co więcej, prowadzenia życia oddanego Bogu przez mnichów nie można uważać za wymówkę do lenistwa i unikania trudu codziennej pracy $^{44}$.

Mnichom w Sketis zadawano pytanie, czy któryś z nich nie mógłby zamieszkać blisko swych krewnych i z ich dorobku korzystać na własne potrzeby, sam poświęcając się czytaniu i modlitwie. Odpowiedź była negatywna, ponieważ w rozumieniu mnichów taki brat nigdy nie stałby się mnichem, lecz pozostawały wciąż osobą świecką, gdyż tak naprawdę przez swą zależność od swych świeckich krewnych nie odłączyłby się nigdy od świata, co stanowi fundament życia monastycznego. Tymczasem praca zapewnia mnichowi i każdemu człowiekowi niezależność i wolność pod każdym względem, chroniąc przed pójściem na ludzkie kompromisy i przed wchodzeniem w ludzkie, mało przejrzyste sprawy ${ }^{45}$. Jeżeli mnich nie zapewni sobie pożywienia własną pracą, będzie zmuszony do korzystania z pomocy ludzi bogatych, „do dzielenia stołu z bogaczami” i uzależnienia się od nich, przed czym przestrzega się w znanej mnichom Starotestamentalnej

\footnotetext{
${ }^{42}$ Benedykt z Nursji, Reguła 48, 8: „właśnie wówczas są prawdziwymi mnichami, jeśli żyją z pracy rąk swoich, jak Ojcowie nasi i Apostołowie”.

${ }^{43}$ (Mt 10, 10): „Wart jest bowiem robotnik swej strawy”.

${ }^{44}$ BAzyli Wielki, Reguły dłuższe, w: Pisma ascetyczne, t. 2. Źródła monastyczne t. 6, (red. M. Starowieyski), Kraków 1995, pytanie 37, s. 145.

${ }^{45}$ A. Guillaumont, U źródeł monastycyzmu chrześcijańskiego, t. 1, w: Źródła monastyczne t. 37 (red. M. Starowieyski), Kraków 2006, s. 168-169.
} 
Księdze Przysłów, w której stwierdza się jasno, że pokarm pochodzący od możnych jest zwodniczy ${ }^{46}$.

Początkom monastycyzmu nie były jednak obce próby ucieczki mnichów od życia pracowitego pod pozorem bezgranicznego zaufania Opatrzności Bożej i chęci przeznaczenia więcej czasu na modlitwę. Nawiązywali oni do zachęty św. Pawła do nieustannej modlitwy (1 Tes 5,17). W klasztorach Kartaginy (ok. 401 r.) mnisi, wychodząc od niewłaściwej interpretacji fragmentu Pisma Świętego: [„Przypatrzcie się ptakom w powietrzu: nie sieją ani żną i nie zbierają do spichrzów, a Ojciec wasz niebieski je żywi. Czyż wy nie jesteście ważniejsi niż one?” (Mt 6, 26) ${ }^{47}$ ], chcieli żyć tylko z ofiar innych ludzi. Dyskusja nad słusznością takiego sposobu postępowania przeniosła się także poza mury klasztoru i była żywa we wspólnocie chrześcijańskiej tego miasta. Zabrał w niej głos św. Augustyn poprzez traktat pt. De opere monachorum, w którym wyjaśnił, jak należy połączyć zaufanie Bogu i realizację przykazania pracy, głoszonego przez św. Pawła ${ }^{48}$.

\subsubsection{1. „Bezczynność jest wrogiem duszy”49}

Bezczynność, jako lenistwo, była potępiana przez pokolenia mnichów głównie ze względu na zagrożenie, jakie niesie ona ze sobą dla życia duchowego leniucha ${ }^{50}$. Praca w życiu monastycznym nie sprowadza się bowiem tylko do zarobkowania na własne utrzymanie mnichów i uprawiania dobroczynności, ale przede wszystkim ma przyczyniać się do rozwoju duchowego, któremu na przeszkodzie

\footnotetext{
${ }^{46}$ Prz 23,1-3.

${ }^{47} 2$ Tes 11-12: „Słyszymy bowiem, że niektórzy wśród was postępują wbrew porządkowi: wcale nie pracują, lecz zajmują się rzeczami niepotrzebnymi. Tym przeto nakazujemy i napominamy ich w Panu Jezusie Chrystusie, aby pracując ze spokojem, własny chleb jedli".

${ }^{48}$ Augustyn z Hippony, O pracy mnichów..., s. 185-267; P. Nehring, Wstęp, w: Św. Augustyn. Pisma monastyczne. Źródła monastyczne t. 27, (red. M. Starowieyski), Kraków 2002, s. 83-99; A. De Vogüe, Lavoro. III. In Occidente, kol. 518.

${ }^{49}$ Benedy Kt z Nursji, Reguła 48, 1.

${ }^{50}$ W. Zatorski, Komentarz do Reguły św. Benedykta, Tyniec 2012, s. 238-239.
} 
stała tzw. acedia, skutkująca lenistwem ${ }^{51}$. Acedia, będąca chorobą samotności, zniechęcenia i znużenia, zwana też „demonem południa" sprawiała, że mnich stopniowo zaniedbywał swe życie duchowe, opuszczał celę, aż w końcu porzucał życie monastyczne. Choroba ta była więc bardzo groźna w swych skutkach, niszcząc element istotny dla życia mniszego, tj. gorliwość i wytrwałość w przebywaniu w celi, a tym samym - wewnętrzne wyciszenie, milczenie i wsłuchiwanie się w Słowo Boże, czyli tzw. hesychię, od której pustelnika określano często mianem hezychasty ${ }^{52}$. Środkiem zaradczym, skutecznym lekarstwem na acedię, była wytrwała modlitwa oraz sumienne wykonywanie codziennej pracy ${ }^{53}$. Acedia, będąca jedną z ośmiu złych myśli wyróżnianych przez Ewagriusza z Pontu, znalazła się następnie w spisie siedmiu grzechów głównych przekazanych na Zachód przez Kasjana i Grzegorza Wielkiego. Termin acedia został zastąpiony przez pojęcie lenistwa, czyli znużenia duchowego i w tej formie utrwaliła się w obowiązującym Katechizmie Kościoła Katolickiego jako siódmy grzech główny ${ }^{54}$.

W związku z tym, że praca przyczyniała się do zachowania hesychii, tak ważnej dla życia samotnego, była łączona a nawet utożsamiana $\mathrm{z}$ ascezą monastyczną, czyli z trudem, wysiłkiem, ćwiczeniem się w dobru. Na pytanie, kto to jest mnich, niektórzy mnisi, odpowiadali wprost, że jest to „trud”, ”mozolna praca”, „szukanie trudu w każdej pracy". Gdyby więc z życia mnichów został wyeliminowany trud w postaci pracy fizycznej lub duchowej, automatycznie przestawaliby oni być mnichami ${ }^{55}$.

${ }^{51}$ Tamże, s. 244-245; A. Guillaumont, U źródeł monastycyzmu chrześcijańskiego, s. 170 .

${ }^{52}$ Greckie słowo hesychia oznacza stan spokoju, wyciszenia serca, czujności, milczenia wewnętrznego, skupienia i nieustannego myślenia o Bogu.

${ }^{53}$ Ewagriusz z Pontu, O praktyce [ascetycznej] 12, w: Pisma ascetyczne. T.1, Źródła monastyczne, t. 18, s. 208-209; G. Bunge, Ewagriusz z Pontu-mistrz życia duchowego, w: Źródła monastyczne, t. 19, s. 165-306.

${ }^{54}$ Katechizm Kościoła Katolickiego, Poznań 1994, nr 1866, 2094; A. Guillaumont, U źródeł monastycyzmu chrześcijańskiego, s. 170-171.

${ }^{55}$ A. Guillaumont, U źródet monastycyzmu chrześcijańskiego, s. 172. 
Św. Benedykt dla uniknięcia bezczynności mnichów i zabiegając o to, aby byli oni prawdziwymi mnichami, zalecał im zajmowanie się $\mathrm{w}$ ustalonych godzinach pracą, a w innych - czytaniem duchownym, które jest również pracowite, gdyż jest to czytanie na głos ${ }^{56}$.

$\mathrm{Z}$ treści Reguty św. Benedykta wynika, że pracują także, odpowiednio do swych możliwości, mnisi chorzy. Może się zdarzyć, że długotrwała choroba skłania mnicha do porzucenia pracy, wprowadza w stan rozleniwienia, stąd Benedykt zaleca w Regule: „Niechaj bracia chorzy lub słabi otrzymują takie zajęcia, żeby nie groziła im bezczynnośc'" ${ }^{7}$.

Troska św. Benedykta o wyeliminowanie bezczynności z życia niedbałych i leniwych mnichów była tak wielka, że w niedzielę, mimo świątecznego charakteru dnia, jeżeli nie chcieli oni zająć się czytaniem lub medytacją, zlecał im do wykonania jakąś pracę, wiedziano bowiem, że mnich pozostawiony bez pracy zajmuje się czynnościami często irracjonalnymi ${ }^{58}$.

Afirmacja pracy w nauczaniu św. Benedykta nie jest bynajmniej stanowiskiem odosobnionym czy wyjątkowym. Również św. Bazyli lenistwo mnicha uważał za wielkie zło ${ }^{59} \mathrm{i}$ łączył je z opisem sługi złego i gnuśnego w Ewangelii św. Mateusza ${ }^{60}$.

\footnotetext{
${ }^{56}$ Benedy kt z Nursji, Reguła, rozdz. 48,1. Czytanie duchowne w tym czasie polegało na głośnym czytaniu, gdyż nie znano sztuki cichego czytania, stąd było ono wysiłkiem zarówno intelektualnym jak i fizycznym, wymagało koncentracji zważywszy, że lektura zajmowała mnichom około 2 godzin dziennie. W. ZATORsKi, Komentarz do Reguły św. Benedykta, s. 240-241.

${ }^{57}$ Benedy kt z Nursji, Reguła, 48, 24.

${ }^{58}$ Benedy kt z Nursji, Reguła, 48, 23: „Jeśli zaś ktoś jest tak niedbały i leniwy, że nie chce albo nie może ani rozmyślać, ani czytać, trzeba mu zlecić jakąś pracę do wykonania, aby nie był bezczynny"; R. SzmurŁo, Życie monastyczne w pismach Szenutego z Atripe, Warszawa 2001, s. 152.

${ }^{59}$ BAZYli Wielki, Reguły dtuższe, pytanie 37, 2.

${ }^{60}$ Mt 25, 26: „Sługo zły i gnuśny”.
} 


\subsubsection{Przepracowywanie się}

Pracowici mnisi zdawali sobie sprawę ze szkodliwości lenistwa, ale też i z nadmiernego oddawania się pracy - przepracowywania się, które również przytłaczało, a czasem nawet skłaniało do opuszczenia życia klasztornego ${ }^{61}$. Takie następstwo wywierał nadmiar pracy, zarówno tej związanej z rozwojem duchowym, jak i pracy fizycznej. Skutki przeciążenia $\mathrm{w}$ pracy ukazane zostały obrazowo $\mathrm{w}$ anegdocie z życia św. Antoniego Pustelnika. Gdy jeden z przechodzących myśliwych gorszył się traceniem przez świętego czasu na żartobliwą rozmowę z braćmi, Antoni kazał mu założyć strzałę i napiąć łuk tak mocno, że myśliwy obawiał się, iż łuk pęknie. Św. Pustelnik skonkludował, że podobnie jest z pracą wewnętrzną. Powiedział: „jeśli ją ponad miarę napniemy, bracia się szybko załamią" ${ }^{62}$. Chciał w ten sposób dać do zrozumienia, że konieczny jest umiar, zarówno w wykonywaniu pracy fizycznej jak i duchowej.

Św. Benedykt, którego Reguła zaleca umiar w każdym aspekcie życia monastycznego, wskazywał na potrzebę dawania mnichom pomocników przy wykonywaniu cięższych prac klasztornych, np. w kuchni czy ogrodzie, aby zapobiec przepracowaniu braci ${ }^{63}$. Jeżeli któryś mnich potrzebowałby pomocy, powinien ją otrzymać. Jeśliby natomiast sam miał więcej wolnego czasu, to wykonywał dodatkowe prace polecone mu przez przełożonego klasztoru ${ }^{64}$. Podobnie św. Pachomiusz wyraził się w swej Regule, zalecając, aby nie przymuszać braci do ciężkiej pracy, zachęcając, aby praca była dobrze wymierzona,

${ }^{61}$ Benedy t z nursji, Reguła, 48,24: „żeby nie groziła im bezczynność, lecz jednocześnie, by nadmiar roboty ich nie przytłaczał lub nie skłaniał do odejścia”.

${ }^{62}$ Apoftegmaty ojców pustyni. t. 1.Geronticon. Źródła monastyczne (red. M. Starowieyski), t. 4, Kraków 2007, 13(13) s. 133.

${ }^{63}$ Benedy kt z Nursji, Reguła, rozdz. 35, 3-4: „Słabszym trzeba dać pomocników, aby nie spełniali tej pracy z przykrością. Zresztą wszyscy powinni mieć pomocników stosownie do liczebności wspólnoty i miejscowych warunków”.

${ }^{64}$ Tamże, rozdz. 53,18: „Gdyby potrzebowali pomocy, trzeba im ją przydzielić, aby swoją posługę wypełniali bez szemrania. A z drugiej strony w czasie, kiedy byliby mniej zajęci, niechaj pójdą do pracy tam, dokąd ich poślą". 
tak, aby pobudzała mnichów do większej pilności ${ }^{65}$. Jeżeli natomiast jakiś brat ma zwyczaj szemrania i użalania się z powodu rzekomego przeciążenia pracą, będzie się go pięciokrotnie upominać, że szemrze bezzasadnie. Jeżeli nadal upiera się przy swoim zdaniu, zostanie uznany za chorego i umieszczony wśród chorych, aż zrozumie prawdę o swej tendencji do lenistwa. Gdyby zaś jego użalanie okazało się słuszne, bo istotnie był uciskany przez przełożonego namiarem zajęć, wówczas tę samą karę miał ponieść przełożony ${ }^{66}$.

\section{Prymat zbawczego charakteru pracy mniszej}

Trzeba podkreślić, że celem całokształtu pracy anachoretów, a zwłaszcza mnichów zamieszkujących w klasztorach, nie była produkcja dóbr materialnych, chociaż praca w klasztorach była dobrze zorganizowana, a one same przypominały prawdziwe manufaktury. Wbrew pozorom głównym zadaniem mnichów była praca nad wspólnym zbawieniem ${ }^{67}$. Postulat wykonywania pracy dla osiągnięcia zbawienia wybrzmiewa już w apoftegmatach ojców pustyni. Myśl ta znalazła wyraz $\mathrm{w}$ jednym $\mathrm{z}$ apoftegmatów pierwszego $\mathrm{z}$ nich - ojca pustelników $^{68}$. Na pytanie świętego Antoniego skierowane do Boga, co ma uczynić, aby się zbawić, ponieważ najbardziej przeszkadzają mu w tym myśli, święty zobaczył kogoś podobnego do siebie, kto siedział i pracował, a następnie wstawał i modlił się. Potem znowu siadał i plótł linę, i ponownie powstawał do modlitwy. Przy czym Antoni usłyszał głos anioła, aby czynił podobnie, a będzie zbawiony. Charakter zbawczy pracy znalazł więc swe potwierdzenie już w początkach życia pustelniczego i był bardzo żywy wśród anachoretów. Abba Apollos, gdy proszono go o wykonanie jakiejś pracy, szedł

${ }^{65}$ PAchomiusz, Przykazania i prawa 3(179), w: Pachomiana latina. Źródła monastyczne, t. 11, (red. M. Starowiejski) Kraków 1996, s. 170.

${ }^{66}$ Tenże, Reguła - Przykazania i orzeczenia 5(164), w: Pachomiana latina. Źródła monastyczne, t. 11, (red. M. Starowiejski) Kraków 1996, s. 166.

${ }^{67}$ M. Kanior, Historia monastycyzmu chrześcijańskiego, t. 1. Starożytność (wiek III-IV), Kraków 1993, s. 67; A. GuILlaumont, U źródeł monastycyzmu chrześcijańskiego, s. 166.

${ }^{68}$ Atanazy Aleksandryjski, Żywot św. Antoniego, s. 166, 1. 
zawsze z radością, mówiąc: „Dzisiaj będę pracował z Chrystusem dla zbawienia mojej duszy: taka jest bowiem dla niej nagroda"69. Nietrudno zrozumieć, dlaczego, gdy wymiar duchowy pracy zaczynano lekceważyć, przywiązując większą wagę do strony produkcyjnej, skutkowało to kryzysem klasztoru, jak stało się to na przykład w przypadku monastycyzmu pachomiańskiego ${ }^{70}$.

\section{Szczególne uzdolnienia mnichów i prace im zalecane}

Anachoreci wykonywali prace proste, które nie wymagały dużego nakładu środków, czyli na przykład kosztownych surowców, dobrze wyposażonych warsztatów, a także -długiego i skomplikowanego przygotowania do zawodu. Najczęściej mnisi uprawiali plecionkarstwo. Wyplatali kosze, maty i liny, zajmowali się tkactwem, uprawiali ogródki przy eremach, w czasie żniw - najmowali się do pracy w polu w zamian za zboże ${ }^{71}$. Natomiast w życiu klasztornym, już w pierwszych wspólnotach pachomiańskich można spotkać rzadsze specjalności rzemieślnicze praktykowane przez mnichów, wymagające wcześniejszego wyuczenia zawodu i odpowiednich materiałów. Wśród mnichów spotkać było można: tkaczy, krawców, cieślów, foluszników, szewców, piekarzy, rolników, ogrodników, przepisujących teksty, kowali, stolarzy, garbarzy, poganiaczy wielbłądów, hodowców świnn ${ }^{72}$. Bracia tej samej specjalności zamieszkiwali w jednym domu, pod władzą osobnych przełożonych i co tydzień przedstawiali ojcu

${ }^{69}$ Apoftegmaty ojców pustyni. t. 1. Geronticon. Źródła monastyczne (red. M. Starowieyski), t. 4, Kraków 2007, 1(149), s. 182.

${ }^{70}$ M. Kanior, Historia monastycyzmu chrześcijańskiego, s. 67.

${ }^{71}$ E. Wipszycka, Wstęp, w: Apoftegmaty ojców pustyni. t. 1.Geronticon. Źródła monastyczne (red. M. Starowieyski), t. 4, Kraków 2007, s. 56; Tenże, Z dziejów monastycyzmu egipskiego IV-VIII w., Warszawskie Studia Teologiczne 3(1985-90), s. 224-244.

${ }^{72}$ Palladiusz, Pachomiusz i mnisi z Tabennesis, w: Pachomiana latina. Źródła monastyczne, t. 11, (red. M. Starowiejski) Kraków 1996, s. 105-106; R. SzmurŁo, Życie monastyczne w pismach Szenutego z Atripe, s. 155. 
klasztoru rozliczenie z ukończonych $\operatorname{prac}^{73}$. W późniejszych wiekach mnisi zajmowali się także przepisywaniem ksiąg i ich oprawą ${ }^{74}$. Wykonywana przez anachoretę lub mnicha praca nie powinna była burzyć ich wewnętrznego pokoju, budzić ambicji ani też dawać satysfakcji ${ }^{75}$. Prace, które polecano mnichom, były starannie dobierane na podstawie analizy wpływu, jaki mogły mieć na braci. Przykładowo pod względem dochodów np. tkactwo przynosiło większe korzyści mnichowi niż plecionkarstwo, wymagało jednak licznych kontaktów z ludźmi świeckimi, ponieważ wytwory były wykonywane na ich zlecenie i z surowców przez nich dostarczonych. Wymuszało to na mnichu konieczność umawiania się i targowania, stąd o tkaczach mówiono, że nie są mnichami, lecz handlarzami i nie polecano tego rodzaju pracy ${ }^{76}$.

Św. Bazyli Wielki zachęcał do podejmowania takiej pracy, która nie narusza pokoju i porządku życia monastycznego i - w warunkach jego czasów - nie nastręcza trudności w zdobyciu środków koniecznych do jej wykonywania i w sprzedaży wytworów, a poza tym nie wiąże się z niestosownym i szkodliwym przebywaniem mnicha w towarzystwie mężczyzn i kobiet. Gdyby zaś jakiś rodzaj pracy zakłócał życie braterskie, nie pozwalał na prowadzenie życia w skupieniu i trwaniu przy Panu, odciągał od wspólnej modlitwy, należało z niej bezwzględnie zrezygnowaćc ${ }^{77}$. Miernikiem stosowności pracy dla mnicha był też stopień jej prostoty i skromności, stąd nie wszystkie zgłaszane zamówienia przez ludzi spoza klasztoru należało realizować. Przykładowo - podczas pracy tkackiej mnich mógł wykonywać

\footnotetext{
${ }^{73}$ Św. Hieronim, Przedmowa do Reguły św. Pachomiusza, w: Pachomiana latina. Źródła monastyczne, t. 11, Kraków 1996, s. 126 (cal 123-127).

${ }^{74}$ E. Wipszycka, Wstęp, w: Apoftegmaty ojców pustyni. t. 1. Geronticon. Źródła monastyczne (red. M. Starowieyski), t. 4, Kraków 2007, s. 56.

${ }^{75}$ E. Wipszycka, $Z$ dziejów monastycyzmu egipskiego IV-VIII w., Warszawskie Studia Teologiczne 3(1985-90), s. 228.

${ }^{76}$ Tamże, s. 231.

${ }^{77}$ BAzyli Wielki, Reguły dłuższe, pytanie 38.
} 
tylko rzeczy używane na co dzień, nie zaś wytworne, bezużyteczne, będące w użytku ludzi rozrzutnych ${ }^{78}$.

Św. Benedykt z kolei wspomina w swej Regule o najbardziej elitarnej grupie mnichów pracujących w klasztorach. Stanowili ją rzemieślnicy, odznaczający się szczególnymi zdolnościami i umiejętnościami, którym pozwalano na wykonywanie swej pracy z pokorą. Przy czym, zgodnie z wyznawaną zasadą, że praca ma sprzyjać rozwojowi duchowemu, gdyby skłaniała ona mnicha do pychy należało odsunąć go od zawodu, nawet wtedy, jeżeli praca ta przynosiłaby duże dochody dla klasztoru, a rezygnacja $\mathrm{z}$ niej wiązałaby się $\mathrm{z}$ dużą stratą finansową ${ }^{79}$. W hierarchii wartości zawsze stawiano wyżej dobro duchowe mnicha niż dobra materialne i artystyczne klasztoru. Podobnie też postępowano przy sprzedaży produktów klasztornych. W myśl ewangelicznej zasady, że „korzeniem wszelkiego zła jest chciwość pieniędzy" (1 Tm 6,10), należało unikać wszelkiej nieuczciwości przy zbywaniu produktów, nie dopuszczać chciwości przy ustaleniu ceny wyrobów i lepiej było sprzedać taniej niż czynili to świeccy ${ }^{80}$. Według św. Bazylego korzystniej było sprzedać produkty po niższych cenach w pobliżu klasztoru, niż w poszukiwaniu wyższych cen sprzedaży, dla uzyskania niewielkiego zysku, udawać się daleko poza klasztor i włączać się w życie świata ${ }^{81}$.

Widocznym jest, że z wykonywaniem pracy, zwłaszcza przez anachoretów, wiązał się problem sprzedaży wytworzonych przez nich produktów i kupno materiałów oraz sprzętów, których nie można było wytworzyć w klasztorze. Najczęściej sami mnisi sprzedawali swoje wyroby i kupowali materiały na rynkach miejskich, a, wchodząc w relacje z ludźmi świeckimi, często tracili swe powołanie do życia

\footnotetext{
${ }^{78}$ Tamże.

${ }^{79}$ Benedy kt z Nursji, Reguła, rozdz. 57.

${ }^{80}$ Tamże, rozdz. 57, 7-9.

${ }^{81}$ BAZyli Wielki, Reguły dłuższe, w: Tenże, Pisma ascetyczne, t. 2. Źródła monastyczne (red. M. Starowieyski), Kraków 1995, t. 6, pytanie, 6, 33, 39, 40, 44; E. BoAGA, La clausura. Origine e sviluppo storico-giuridico-spirituale, Vita Consecrata 29(1993), s. 493; Por. J. Prou, (e le monache della Congregazione di Solesmes, O.S.B.), La clausura delle monache, prospettive della vita religiosa, Città del Vaticano 1998, s. 72.
} 
poświęconego Bogu. Poza tym mnich, wyrzekając się świata, wyrzekał się jednocześnie wszelkiej związanej z nim aktywności, do której należały transakcje handlowe obejmujące sprzedaż wytwarzanych przez siebie produktów. Kreowały one szereg trosk i kłopotów w postaci skrupulatnego targowania się o cenę, kłótliwość, krzywoprzysięstwo, stąd zlecenie sprzedaży produktów powierzano ludziom świeckim, a - jeżeli było to niemożliwe - to przynajmniej rezygnowano z troski o sprawiedliwą cenę sprzedawanych towarów ${ }^{82}$. Poza tym handel nie należał do kategorii prac fizycznych zalecanych mnichom, ze względu na to, że nie pozostawiał on, w czasie dokonywania transakcji, wolności umysłu i serca, mogących pozwolić w tym czasie oddawać się modlitwie. Handlujący mnich musiał zaangażować się umysłowo w swą działalność, pozbawiając się tym samym pełnej swobody relacji z Bogiem. Handel stwarzał też niebezpieczeństwo szybkiego wzbogacenia się i w konsekwencji - porzucenia przez mnicha właściwego mu celu życia ${ }^{83}$.

\section{Praca umożliwia dobroczynność}

Mnisi, realizując ewangeliczną zachętę do wspomagania ludzi potrzebujących, a zwłaszcza, aby wypełnić słowa Chrystusa: „Wszystko, co uczyniliście jednemu z tych braci moich najmniejszych, Mnieście uczynili” oraz „Wszystko, czego nie uczyniliście jednemu z tych najmniejszych, tegoście i Mnie nie uczynili”, wykonywali swą pracę nawet wtedy, gdy już zapracowali na własne potrzeby ${ }^{84}$. Kiedy św. Bazylego zapytano o cel pracy mniszej oraz o to, jakie powinno być nastawienie ducha w czasie jej wykonywania, odpowiedział on, że celem pracy nie jest służenie własnym potrzebom, lecz pomoc ubogim ${ }^{85}$,

\footnotetext{
${ }^{82}$ R. SzmurŁo, Życie monastyczne w pismach Szenutego z Atripe, s. 150; A. GuILLAUMONT, U źródeł monastycyzmu chrześcijańskiego, s. 172-173.

${ }^{83}$ P. Nehring, Pisma monastyczne św. Augustyna, w: Św. Augustyn, Pisma monastyczne. Źródła monastyczne, t. 27, (red. M. Starowieyski), Kraków 2002, s. 96.

${ }^{84}$ Mt 25,35-45.

${ }^{85}$ BAzyli Wielki, Reguły dłuższe, pytanie 42, s. 157-159; U. Neri, Fondatori del monachesimo, Casale Monferrato 1998, s. 93.
} 
by zadośćuczynić obowiązkowi miłosierdzia i dać innym braciom, to co dla nich jest potrzebne ${ }^{86}$.

Jeden $\mathrm{z}$ anachoretów wyplatał nocą liny, chociaż nie służyły mu one do wymiany na środki potrzebne do życia. Nie chciał jednak, aby Bóg mu kiedyś zarzucił: „Dlaczego nie pracowałeś, kiedy mogłeś?”" Inny mnich, mieszkający daleko od osiedli ludzkich, żył z uprawy własnego ogródka, jednak bezustannie pracował, aby nie ulec demonowi acedii i każdego roku palił plony swej pracy, nie mogąc ich sprzedać ${ }^{88}$.

Nadwyżki swych produktów mnisi przeznaczali także na potrzeby klasztorów żeńskich i więźniów ${ }^{89}$. Najmując się do pracy przy żniwach, dzielili zapłatę na dwie części, przeznaczając jedną z nich na jałmużnę, a drugą - na własne potrzeby. Poza tym przekazywano potrzebne środki poszkodowanym z powodu klęsk żywiołowych. Były one wyrazem prawdziwej ofiary składanej Bogu z pracy własnych rąk mnichów ${ }^{90}$.

Z powyższego opisu jasno wynika, że owoce pracy mnichów służyły nie tylko im samym, dla zaspokojenia ich własnych, skromnych skądinąd wymagań, ale także potrzeb innych osób. Praca zatem stanowiła akt solidarności z ludźmi, była darem z samego siebie danym bliźniemu. Dzięki pracy realizował się ideał wspólnoty chrześcijańskiej. Ten zaś, kto świadomie i dobrowolnie oddawał się bezczynności, był uważany za egoistę, szkodzącego wspólnocie chrześcijańskiej, czy w szerszym wymiarze - ludzkiej ${ }^{91}$. Sam Chrystus jest tu wzorem do

${ }^{86}$ Ef 4,28: „Kto dotąd kradł, niech już przestanie kraść, lecz raczej niech pracuje uczciwie własnymi rękami, by miał z czego udzielać potrzebującemu”; BAZYLI Wielki, Reguły dłuższe, pytanie 37, 1.

${ }^{87}$ Apoftegmaty ojców pustyni. t. 1.Geronticon. Źródła monastyczne (red. M. Starowieyski), t. 4, Kraków 2007, 5(128) s. 171-172.

${ }^{88}$ A. Guillaumont, U źródeł monastycyzmu chrześcijańskiego, s. 170-171.

${ }^{89}$ Palladiusz, Pachomiusz i mnisi z Tabennesis, w: Pachomiana latina. Źródła monastyczne, t. 11, (red. M. Starowiejski) Kraków 1996, s. 105, 9.

${ }^{90}$ L. Dattrino, Il primo monachesimo, s. 184; A. De Vogüe, Lavoro. III. In Occidente, kol. 521.

${ }^{91}$ L. Civardi, Il lavoro nel concetto cristiano, s. 40-41. 
naśladowania, gdyż przyszedł, aby służyć innym, nie zaś - przyjmować służbę innych ${ }^{92}$. Podobnie czynił i pisał św. Paweł Apostoł: „We wszystkim pokazałem wam, że tak pracując trzeba wspierać słabych i pamiętać o słowach Pana Jezusa, który powiedział: «Więcej szczęścia jest w dawaniu aniżeli w braniu»" 93 .

\section{Sposób wykonywania pracy}

Mnisi pracowali najczęściej w milczeniu i skupieniu. W żadnym wypadku nie mogli w czasie pracy rozmawiać o rzeczach świeckich, śmiać się czy wykrzykiwać, lecz powinni byli rozmyślać o rzeczach świętych, śpiewać psalmy i wysławiać Pana w swych sercach ${ }^{94}$. Stąd do mniszych warsztatów pracy nie można było wchodzić mnichom obcym. Gdyby tak się zdarzyło, mnichowi naruszającemu porządek i harmonię wspólnoty wyznaczano pracę bardziej uciążliwą, dopóki nie nauczył się on trwania przy własnej pracy, do jakiej Bóg go powołał ${ }^{95}$. W czasie wykonywania wspólnych prac, dla zachowania milczenia recytowano fragmenty Pisma Świętego - najczęściej psalmy. Modlitwa nie tylko rozpoczynała i kończyła pracę cenobitów

\footnotetext{
${ }^{92}$ Mt 20,28: „A kto by chciał być pierwszym między wami, niech będzie niewolnikiem waszym, na wzór Syna Człowieczego, który nie przyszedł, aby Mu służono, lecz aby służyć i dać swoje życie na okup za wielu»”; Dz 20, 35: „Więcej szczęścia jest w dawaniu aniżeli w braniu”.

${ }^{93} \mathrm{Dz} 20,35$.

${ }^{94}$ Ef 5.19; PACHomiusz, Reguła-Przykazania 60: „W czasie pracy niech nie rozmawiają o rzeczach świeckich, lecz niech albo rozmyślają o rzeczach świętych, albo przynajmniej milczą”, 68, 116: „Kiedy wlewają wodę do mąki [piekarze - B. Sz.] i wyrabiają ciasto, niech jeden nie odzywa się do drugiego. Gdy rankiem wsadzają na desce chleby do pieca lub składają je do koszów, nie będą rozmawiać i dopóty będą śpiewać psalmy i coś z Pisma Świętego, aż ukończą robotę. Gdy będą czegoś potrzebować, nie będą mówić, lecz dadzą znak tym, którzy mogą przynieść im to, czego potrzebują"; Reguła Mistrza (przekł. M. Dąbek), w: Reguła Mistrza. Reguła św. Benedykta. Źródła monastyczne t. 40, (red. M. Starowieyski), Kraków 2006, rozdz. L, 24-27, s. 255.

${ }^{95}$ BAZYLI WielKi, Reguły krótsze 141, s. 314.
} 
i anachoretów, ale też była obecna w czasie jej wykonywania ${ }^{96}$. Mnisi podejmowali takie prace, jakie wyznaczył im przełożony ${ }^{97}$. Nie mogli przekraczać udzielonego im w tym względzie polecenia. Czasem z powodu zajęć byli zwolnieni z uczestnictwa we wspólnym śpiewie psalmów. Jednak nie mogli być usprawiedliwieni, jeżeli ich nieobecność wynikała z zaniedbania się w pracy i nieukończenia jej we właściwym czasie ${ }^{98}$.

Narzędzia pracy traktowano jak przedmioty oddane i poświęcone Bogu, jak naczynia święte z ołtarza. Gdyby ktoś je zniszczył z niedbalstwa lub lekceważenia - był upominany i oskarżony jako winny świętokradztwa ${ }^{99}$.

Oprócz wykonywania stałej pracy przez poszczególnych mnichów, obowiązywały również tygodniowe dyżury w kuchni, przy zwoływaniu zebrań, sprzątaniu, donoszeniu posiłków pracującym na zewnątrz klasztoru, w refektarzu, opieki na chorymi, rozdzielania narzędzi pracy i służby liturgicznej ${ }^{100}$.

\section{Ascetyczny wymiar pracy}

Mnisi zabiegali o połączenie swej wytrwałej pracy z ascezą, czyli dążyli do tego, aby stawała się ona dla nich sposobnością do podejmowania walki wewnętrznej, wysiłku, do ćwiczenia się w cierpliwości w sytuacjach przykrych, aby mieć tym samym udział w niełatwym życiu Apostołów ${ }^{101}$. Godzili się z tym, że praca jest trudna i wyczer-

${ }^{96}$ R. Szmur£o, Życie monastyczne w pismach Szenutego z Atripe, s. 153; Reguła Mistrza, rozdz. L, 47-52, s. 257.

${ }^{97}$ Pachomiusz, Reguła-Przykazania 123: „Niech nikt bez rozkazu przełożonego nie wykonuje żadnej pracy i niech i niech nie roznosi dzbanów napełnionych wodą, i niech nie wyplata sznurów".

${ }^{98}$ BAzyli Wielki, Reguły krótsze, w: Pisma ascetyczne, t. 2. Źródła monastyczne t. 6, (red. M. Starowieyski), Kraków 1995, pytanie 147, s. 316-317.

${ }^{99}$ Benedy kt z Nursji, Reguła rozdz. 31, 32: Bazyli Wielki, Reguły krótsze, pytanie $143,144$.

${ }^{100}$ Pachomiusz, Reguła-Przykazania 12, 25; Benedy kt z Nursji, Reguła rozdz. 31, 35, 36, 38, 62; R. SzmurŁo, Życie monastyczne w pismach Szenutego z Atripe, s. 157.

${ }^{101}$ BAzyli Wielki, Reguty dłuższe, pytanie 37, 1; 2 Krn 11, 27: „w pracy i umęczeniu, często na czuwaniu, w głodzie i pragnieniu”; A.M. Bellanova, Anacoretismo. Il 
pująca, ukryta, że jej owoce trudno dostrzec, że jest milczącą służbą, która nie przymnaża chwały ludzkiej, a dostrzegana jest tylko przez Boga. Właśnie w tej akceptacji trudności, rezygnacji ze swych pragnień i upodobań mnisi otwierali się na relację $\mathrm{z}$ Bogiem i braćmi ${ }^{102}$. Dodatkowo, zajęcie się pracą uwalniało pustelnika i mnicha od natłoku myśli przeszkadzających w relacji z Bogiem ${ }^{103}$.

Ojcowie pustyni nie pozwalali swym uczniom pod żadnym pozorem, aby pozostawali bezczynni. Często oceniali poziom ich życia duchowego oraz postępy w cierpliwości i pokorze według wykazywanej pilności w pracy. Nie godzili się na to, aby któryś z uczniów korzystał z ofiar innych osób i przeznaczał je na swe wyżywienie. Ukuło się powiedzenie wśród Ojców pustyni, że mnich, który pracuje, jest kuszony przez jednego demona, natomiast ten, który oddaje się bezczynności - przez niezliczoną ich liczbę ${ }^{104}$.

\section{Zakończenie}

Praca, obok modlitwy, czyli służby Bożej, stanowiła istotę życia pierwszych mnichów, co trafnie oddaje benedyktyńska paremia ora et labora. Pierwsi przedstawiciele życia oddanego całkowicie Bogu w Kościele katolickim dążyli do tego, aby praca stawała się jednocześnie ich modlitwą i aby w trakcie jej wykonywania nie tracić ciągłości relacji z Bogiem. Głównym celem pracy, będącej formą naśladowania życia pracowitego Chrystusa i Apostołów, był także udział w Jego zbawczym dziele i zdobycie środków potrzebnych na skromne utrzymanie, zgodne z ubóstwem ewangelicznym. Praca miała dla mnichów również aspekt ascetyczny, gdyż dawała możliwość pokonywania własnych słabości, pełniejszą realizację wymagań zawartych w Ewangelii, a tym samym - dokładniejszego

diritto dei solitari, Pontificia Universitas Lateranensis. Institutum Utriusque Iuris, Theses ad Doctoratum in Ius Canonici, Roma 2004, s. 52-53.

${ }^{102}$ E. GHini, I padri del Deserto, s. 327.

${ }^{103}$ Myśli, jako jedna z podstawowych trudności w życiu pustelniczym bardzo zajmowały bożych samotników, stąd np. Ewagriusz z Pontu poświęcił temu swe dzieło „Walka z myślami”.

${ }^{104}$ L. Dattrino, Il primo monachesimo, s. 185. 
upodabniania się do Chrystusa. Dzięki pracy mnisi mogli również świadczyć pomoc ludziom potrzebującym. Podstawowe zasady co do znaczenia, rozumienia i wykonywania pracy podawały apoftegmaty ojców pustyni i reguły monastyczne, resztę natomiast odkrywał każdy mnich osobiście wraz z wykonywaniem pracy w ciszy i skupieniu oraz nabywaniem doświadczenia ${ }^{105}$. Przy czym wszyscy oni mieli świadomość, że, aby być prawdziwym mnichem, należy „pracować własnymi rękami”.

\section{Meaning of work in life of the first Christian monks}

Work, beside prayer, that is to say God's service were the essence of the first Monks life, what was rightly described by Benedictines' maxim: ora et labora.

First representatives of the life, which was completely given to God in Catholic Church, strived to make their work a prayer at the same time, so they could keep constant relation with God.

Main purpose of work, being a form of imitation of hard-working Christ and Apostles, was also participation in His redemptive work, and obtaining means needed for simple living, in accordance with evangelical poverty.

Work had also ascetic aspect for Monks, because it gave possibility of overcoming their own weaknesses, more complete realization of requirements included in the Gospel, and at the same time more accurately becoming similar to Christ. Thanks to work the Religious could give help to the people in need.

Basic rules regarding meaning, understanding, and performing work were given in Apophthegm of Desert Fathers, and Monastic Rules, whereas the rest had to be personally found out by each Monk, together with fulfillment of their duty performed in silence, and concentration, as well as obtaining experience in art of connecting prayer with work.

At the same time they all were aware, that to be a real Monk meant "to work with their own hands".

${ }^{105}$ BAZyli Wielki, Reguły dłuższe, 43. 
SŁOWA KLUCzOWE: praca; mnich; pustelnik; reguła monastyczna; pracowitość; lenistwo; asceza; dobroczynność

KEY wORDs: work; Monk; Hermit; Monastic Rule; diligence; laziness; asceticism; charity

Nota O Autorze:

S. DR hab. Bożena Szewczul WNO, prof. UKSW - profesor nadzwyczajny na Wydziale Prawa Kanonicznego UKSW w Warszawie, kierownik zakładu Kanonicznych Forma Życia Konsekrowanego w katedrze Ustroju Kościoła i Kanonicznych Form Życia Konsekrowanego. 